\title{
開水路における河床、河岸せん断力の算定法 Calculation of Boudary Shear Stress in Open Channel Flow
}

北海道開発局河川計画課
北海道開発局開発土木研究所
北海道大学工学部

$\begin{array}{rrrrl}\text { 北 } & \text { 條 } & \text { 紘 } & \text { 次 } & \text { Kouji HOJYO } \\ \text { O清 } & \text { 水 } & \text { 康 } & \text { 行 } & \text { Yasuyuki SHIMIZU } \\ \text { 板 } & \text { 倉 } & \text { 忠 } & \text { 興 } & \text { Iadaoki ITAKURA }\end{array}$

A mothod for calculating the velocity field in open channel flows for which boudary shear is an important factor. It is based on the assumption of a scalar eddy viscosity that is proportional to the shear velocity on the actual flow boundary. The 2-dimensional monentum equation produced by this turbulence closure is solved numerically. In a channel with a rectangular cross section, the flow structure depends on both the width- depth ratio and the wall-bed roughness ratio. For such channels, figures to evaluate the boundary shear stress distribution on the bed are provided. The validity of the theory, when applied to sediment transporting flows, is demonstrated using William's(1970) experimental data.

Keywords: boudary shear stress, open channel flow, velocity, bed load transport, eddy viscosity

\section{1. はじめに}

河床変動、河岸侵食、流路変動など流砂に関する問題を扱う場合、水路の底面および河岸即ち潤辺 に沿ったせん断力分布を正確に算定する必要がある。また、流砂を伴う実験においては、水路側壁の 影響を考慮した河床せん断力の算定が不可欠である。開水路の河床せん断力の算定法については、従 来より様々な方法が提案されておりこの結果は江頭ら吕によりまとめられている。このうち、直線水 路における等流の河床せん断力については、最す基本的な問題であるが、断面形状がなだらかな場合 を除いては一般的な方法は確立されていないのが現状である。特に、垂直壁を有する人工水路や河岸 勾配の急な河川等における側岸近傍の河床せん断力を合理的に算定することは、河岸付近の洗掘や側 岸の侵食など河道維持上の問題とも直接的に関係しており、工学上の観点からも重要な課題である。 本研究の目的は、任意の横断形状を有する開水路の河床および河岸に沿ったせん断力分布の算定法の 確立であり、経験的手法や定数を含まない物理的なモデルを用いた合理的な手法の確立を目指すすの である。

\section{2. 基磁方程式と計算法}

直線等流状態の流れにおいて、鈶直方向に $z$ 軸、これに直交する水路横断方向に $n$ 軸をとり、流れ の運動方程式を次式で与える。

$$
\rho g S=\frac{\partial}{\partial z}\left(K \frac{\partial u}{\partial z}\right)+\frac{\partial}{\partial n}\left(K \frac{\partial u}{\partial n}\right)
$$

ここに、 $u$ は流下方向の流速、 $\rho$ は水の密度、gは重力加速度、Sは $x$ 方向の河床勾配(この場合等流な ので $S$ は水面勾配、エネルギ一勾配に一致する)、Kは渦動粘性係数である。(1) 式右辺の第 2 項は横 断方向のせん断力勾配を表し、この項が無ければ無限幅で直線等流状態の運動方程式となり、この項 を除いて (1) 式を $z$ 方向に 2 度積分することにより鉊直方向に対数分布等の流速分布式が得られる。

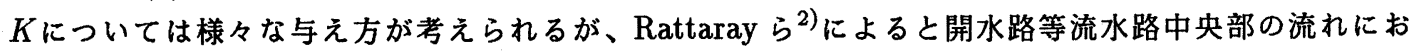
いては次式の表現が最適とされている。

$$
K=k u_{*} z(1-z / D) \quad ; z / D \leq 0.2 \quad(2 \mathrm{a}) \quad K=k u_{*} D / \beta \quad ; z / D>0.2
$$

ここに、kはカルマン常数 $(=0.4) 、 u_{*}$ は摩擦速度、 $D$ は水深、 $\beta$ は定数 $(=6.24)$ である。（ $z$ 軸の原 点は河床にとってある。）(2) 式は河床せん断力（摩擦速度）と河床からの鉛直方向距離のみの関数と 
なっており、水深に対して川幅の広い水路の側岸近傍を除いた領域では高精度の流速分布解が得られ る。しかしながら、一般的には河床だけではなく側岸も含む潤辺のせん断力および潤辺からの距離の 関数とするべきでありここで対象とする 2 次元 $(x, z)$ の流れ場へはこのまま適用できない。ここでは、 図一 1(a)に示すように断面内の主流 $u$ の等流速線 (isovel) に直交する法線 (ray) 求め、この線に沿っ て渦動粘性係数を求める。この場合せん断力は等流速線に沿ってのみ流下方向に作用し、法線に沿っ ては作用しない。従って、流れの混合作用は法線が潤辺と交わる点の閏辺せん断力とそこからの距離 のみの関数となる。実際には、図ー1(b)に示すようにそれぞれの法線は平行にならず各法線は断面 内の最大流速の発生する点に集中するので単に潤辺からの距離ではなく各法線に囲まれた部分の面積 加重距離と考えられる。そこで、(2a) 式に対して次式を仮定する。

$$
K=k u_{*} \ell \gamma
$$

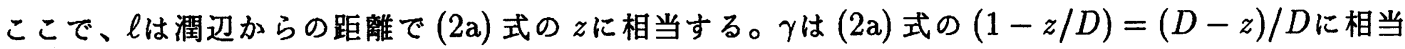
する值であり $D$ と $(D-z)$ に対してそれぞれ図ー1(b) の ABC と ADE とで囲まれる面積を対応させ ると、次式で表される。

$$
\gamma=\frac{\int_{\ell}^{\ell_{m}} d A}{P_{\ell}} / \frac{\int_{0}^{\ell_{m}} d A}{P_{b}}
$$

ここに、 $\ell_{m}$ は法線の長さ、 $P_{\ell}$ は等流速線に沿った法線間の距離 $(\mathrm{BC}) 、 P_{b}$ は潤辺に沿った法線間の距 離 (DE) である。(4) 式の表現から分かるように、あしす法線が平行になると(4) 式の分母、分子はそ れぞれ $(2 \mathrm{a})$ 式の $D 、(D-z)$ に一致し、無限幅水路（側岸の影響が無い）場合に等しくなる。実際に は、(2) 式で水深の 2 割の点で $K$ の表現が変わっているので (3) 式もこれにならって次式の形を採用 する。

$$
K=k u_{*} \ell \gamma \quad ; \quad \int_{0}^{\ell} d A \leq 0.2 \int_{0}^{\ell_{m}} d A \quad(5 \mathrm{a}) \quad K=K_{0} \quad ; \int_{0}^{\ell} d A>0.2 \int_{0}^{\ell_{m}} d A
$$

ここに、 $K_{0}$ は $\int_{0}^{\ell} d A=0.2 \int_{0}^{\ell m} d A$ のときの $K$ の值である。

(1) 式を (5) 式と連立し、境界条件を水面 $(z=D)$ で $\partial u / \partial z=0$ および閏辺から法線に沿って $\ell_{0}\left(\ell_{0}\right.$ は潤辺における粗度高) の距離で $u=0$ として解くことにより与えられた断面形状および勾配におけ る断面内の $u$ の分布が求まる。計算は $(1)$ 式を $(n, z)$ の直交座標において差分法を用いて解き、得ら れた $u$ の等流速線に直交する法線群を求めた後、(5) 式により $K$ の分布を求め、これを用いて $(1)$ 式 を再び解く。以下、uの分布が一定になるまでこれを繰り返し行う。なお、法線の軌跡は $\theta$ を法線と $z$ 軸の角度とすると次式で求めることができる。

$$
\tan \theta=\frac{\partial u}{\partial z} / \frac{\partial u}{\partial n}
$$

潤辺に沿ったせん断力分布は次式により計算される。

$$
\tau_{b}=\rho K \frac{\partial u}{\partial \ell} \quad \text { at } \quad \ell=\ell_{0}
$$



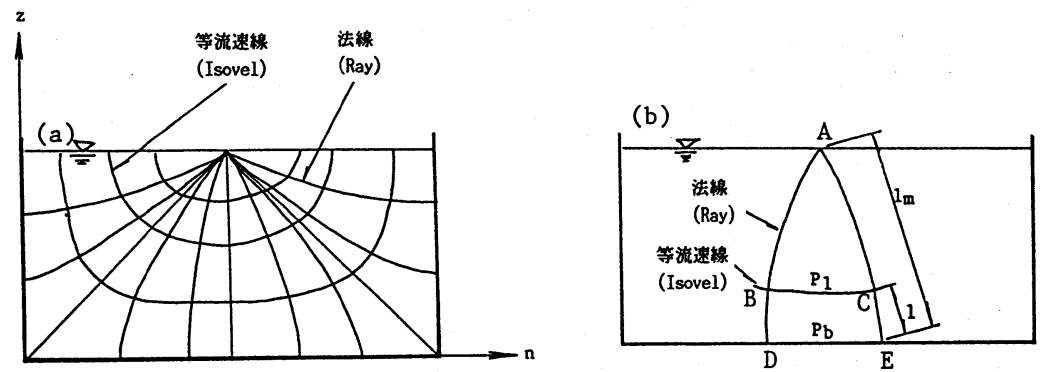

図一 1 直線等流水路における等流速線 (isovel) とこれに直交する法線 (ray)

\section{3. 矩形断面における計算例}

矩形断面における (a) 法線 (ray)、(b) 等流速線、および (c) 河床せん断力の計算結果を図- 2 に示 す。ただし、(c) の綐軸 $R$ は $\tau_{b} / \tau_{0}$ であり $\tau_{0}$ は水深・勾配の積 $(=\rho g D S)$ による河床せん断力である。 側岸の影響が無い場合 $R=\tau_{b} / \tau_{0}=1$ となる。計算条件は後で示す図ー 3,4 の計算条件と併せて表一

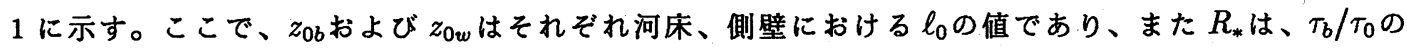
横断方向平均値である。この場合側壁と河床の粗度が等しく、断面形は正方形の下半分の形であり、 流速分布は $z$ 方向と $n$ 方向が対称になっている。最大流速は水路中央の水面に現れており全ての等流 速線に直交する法線は最大流速点に集中している。河床せん断力て 水路中央から左右岸に向かって著しい河床せん断力の低下が見られる。このため、平均の河床せん断 力は、水深・勾配により得られる值の半分 $\left(R_{*}=0.499\right)$ になっている。

図一 3 は、同様の計算を水路幅・水深比を変えて行ったすのである。図ー $3(W / D=8)$ では図一 2 に比べ $W / D$ が大きい分だけ相対的に側壁の影響が小さくなっており、また図ー4 $\left(z_{0 b} / z_{0 w}=0.1\right)$

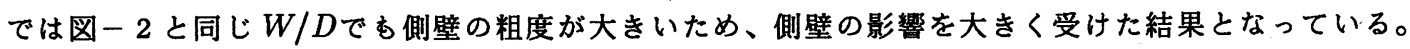
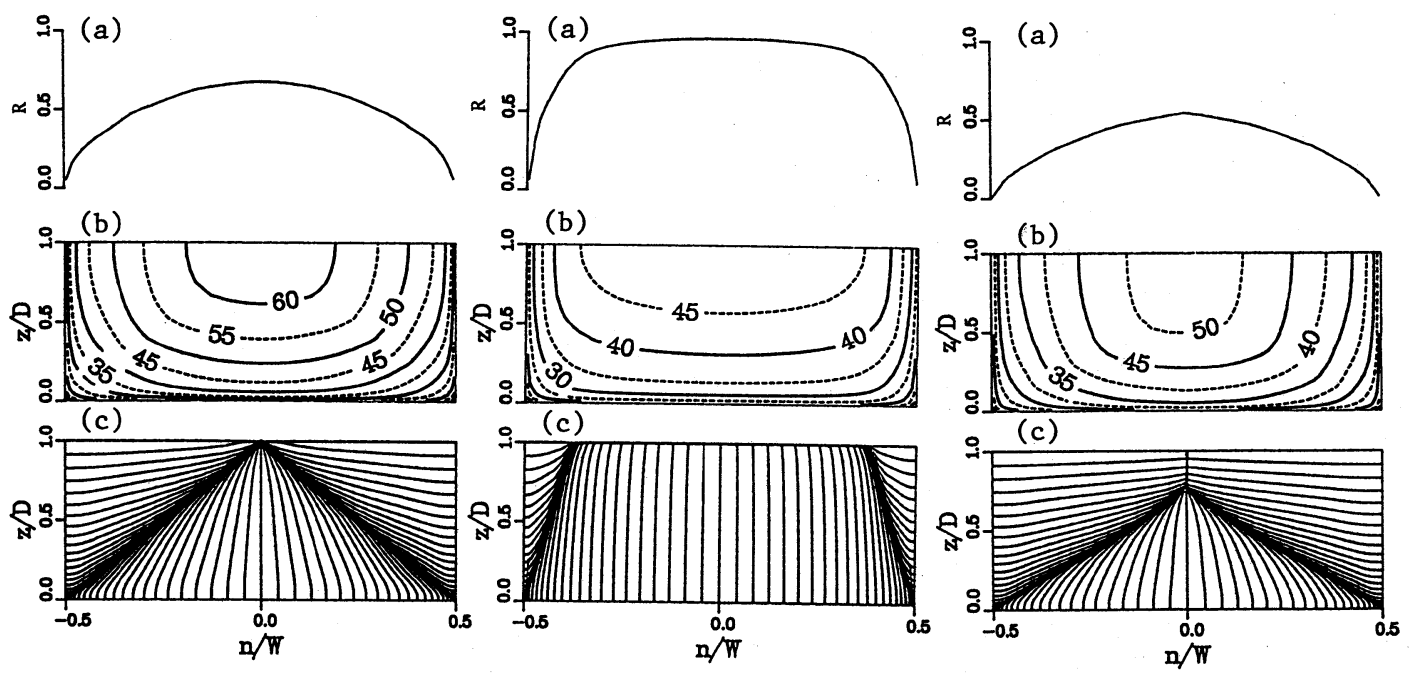

図-2 矩形断面における計算例 図-3 矩形断面における計算例 図-4 矩形断面における計算例 $\left(W / D=2, z_{0 b} / z_{0 w}=1\right)$ $\left(W / D=8, z_{0 b} / z_{0 w}=1\right)$ $\left(W / D=2, z_{0 b} / z_{0 w}=0.1\right)$ 
表 1: 矩形断面水路における計算条件および $R_{*}$ の計算結果

\begin{tabular}{|c|r|r|r|l|l|r|r|}
\hline 図番 & $D(\mathrm{~cm})$ & $W(\mathrm{~cm})$ & $W / D$ & $z_{0 b}(\mathrm{~cm})$ & $z_{0 w}(\mathrm{~cm})$ & $z_{0 b} / z_{0 w}$ & $R_{*}$ \\
\hline 2 & 10.0 & 20.0 & 2.0 & 0.001 & 0.001 & 1.0 & 0.499 \\
\hline 3 & 5.0 & 40.0 & 8.0 & 0.001 & 0.001 & 1.0 & 0.841 \\
\hline 4 & 10.0 & 20.0 & 2.0 & 0.001 & 0.01 & 1.00 & 0.364 \\
\hline
\end{tabular}

\section{4. 河床せん断力と流砂量}

一般に、流砂量を正確に算定するためには河床せん断力の正確な算定が不可欠であるが、特に水路 実験の場合、河床せん断力に対する側壁の影䅧は無視できない場合が多い。ここでは、Williams ${ }^{3)}$ が 広範囲の水路幅・水深比 $(0.28<W / D<20.5)$ を有する直線矩形断面水路において行った掃流砂を伴 う実験データを用い、従来の水深・勾挋法による河床せん断力と前節において述べられた方法による 河床せん断力の比較を行う。Williams ${ }^{3}$ の実験水路はガラス側壁のためほぼ均一の $z_{0 w}$ であるが、河床 形態が流量規模により平坦 (flat)、砂漣 (ripple) 、砂堆 (dune) 、砂州 (bar) と変化しているため、結 果的に河床・側壁の粗度比す非常に広範囲 $\left(20<z_{0 b} / z_{0 w}<1000\right)$ になっている。

図－5 (a) は観測された掃流砂量 $\Phi\left(=q_{b} / \sqrt{s g d^{3}} 、 q_{b}\right.$ は単位幅掃流砂量、 $s$ は砂粒子の水中比重、 $d$

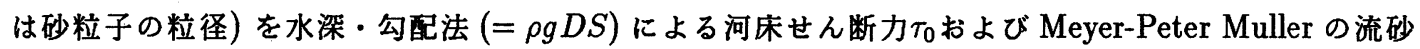
量式と比較したすのである。ここで、図中の記号は水路幅・水深比 $(W / D)$ の範囲を示す。観測值は 全体的に流砂量式から右側にはずれており特に $W / D$ 小さい場合のはずれが大きく、側壁の影響の 大きさを示している。図ー 5 (b) は河床せん断力 $\tau_{0}$ から Wiberg and Smith ${ }^{4}$ の方法を用いて河床形態 による形状抵抗の影響を取り除き、粒子せん断力 (skin friction) $\tau_{s f}$ とした場合である。この結果観測 值は全体的に左方向へ移動し、W/Dの大きいものについては流砂量式との適合度が良くなっている。 一方、図ー5 (c) は本研究の手法により河床せん断力を算出したすのである。但し、側壁の $z_{0 w}$ はガ

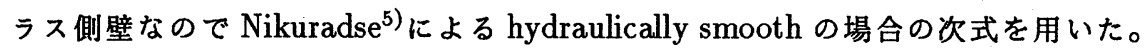

$$
z_{0 w}=\frac{\nu}{9 u_{* w}}
$$

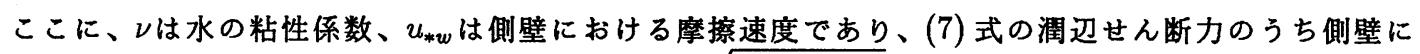
おける值を平均したものをく $\left.\tau_{b}\right\rangle_{w}$ として $u_{* w}=\sqrt{\left\langle\tau_{b}\right\rangle_{w} / \rho て ゙}$ 求めた。また、河床の $z_{0 b}$ は Nelson and Smith ${ }^{6}$ の方法で求めた。図ー 5 (c) では㑡壁の影響が考慮されたため、とくに $W / D$ 小さいす のが左方向へ移動し、ばらついていた観測值全体が集中する傾向がみられる。図-5 (d) は (b) の河 床形態と (c) の側壁の影響の両方を考慮したものであり、観測値全体が流砂量式に適合した結果となっ ている。図ー6は図-5 (d) の結果を他の流砂量式と比較したものであり、いずれる実測值と流砂量 式との適合度は良好である。なお、図-5、6 の横軸の河床せん断力は $(\rho s g d)$ で除して無次元化し てある。

ここで示した例では $W / D$ が 1 以下という極端に狭い水路実験の值す多く含まれているが、このよ うな条件においてす本研究の手法を用いることにより流砂量を合理的に説明することができ、この方 法の有効性を示すすのである。 

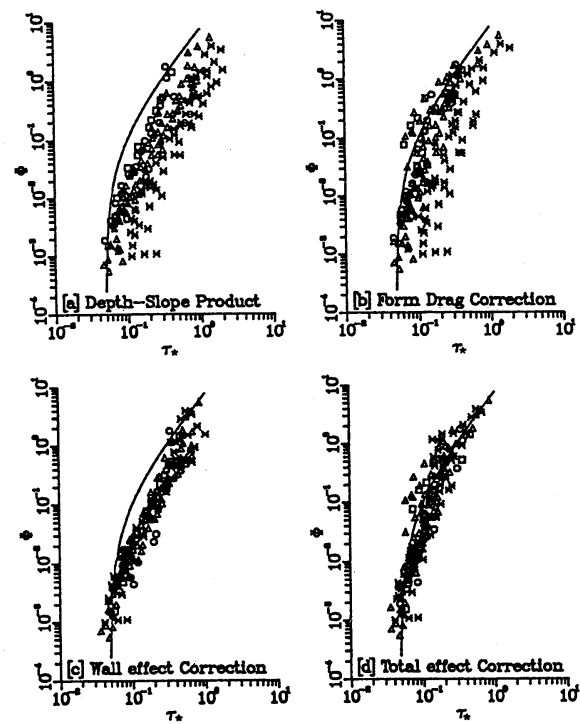

図一 5 河床せん断力と掃流砂量

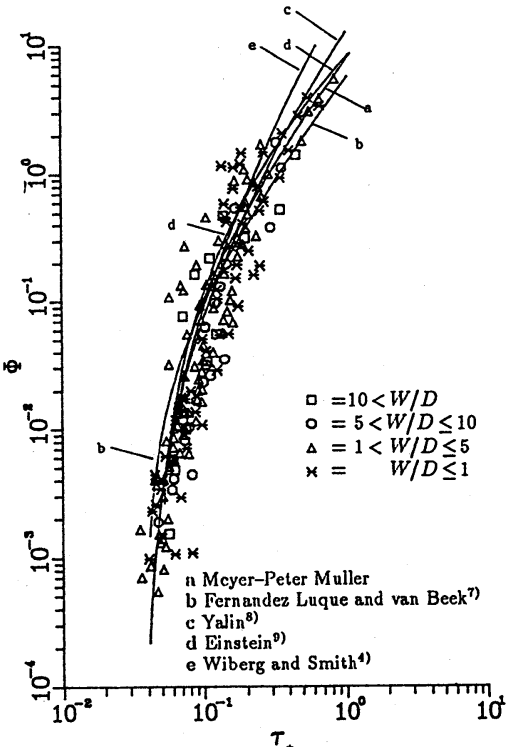

図一 6 河床せん断力と掃流砂量

（各種の掃流砂量式との比較）

\section{5. 潤辺せん断力と流量}

潤辺に沿ったせん断力は流れの内部構造と直接関係するため、流速分布や流量を正確に算出するた めにすその適切な見積が必要である。本節においては、これを流量算定という観点から側壁の影響を 無視した場合（方法 1 ）と考虑した場合（方法 2 ）について検討を行う。

く方法 $1>(1)$ 式の右辺第 2 項を無視し (側壁の影響を無視し)、水面 $(z=D)$ で $\partial u / \partial z=0$ の境 界条件で $z$ 方向に積分すると、次式が得られる。

$$
\rho K \frac{\partial u}{\partial z}=-\rho g S D\left(1-\frac{z}{D}\right)=\tau_{0}\left(1-\frac{z}{D}\right)
$$

$\tau_{0}$ を摩擦速度 $u_{*}$ を用いて $\rho u_{*}^{2}$ で置き換え、渦動粘性係数 $K に(2)$ 式を用い、 $z=z_{0 b}$ で $u=0$ の境界条 件で積分すると次式の流速分布が得られる。

$$
\begin{array}{ll}
\frac{u}{u_{*}}=\frac{1}{k} \ln \frac{\xi}{\xi_{0}} & \xi \leq 0.2 \\
\frac{u}{u_{*}}=\frac{1}{k} \ln \left[\frac{0.2}{\xi_{0}}+\beta\left(\xi-0.5 \xi^{2}-0.18\right)\right] & \xi>0.2
\end{array}
$$

ここで、 $\xi=z / D 、 \xi_{0}=z_{0 b} / D$ であ。水深平均流速く $u>$ は $(10)$ 式を河床から水面まで積分し、水 深で除することにより次式となる。

$$
\frac{<u>}{u_{*}}=\frac{1}{k}\left(\ln \frac{1}{\xi_{0}}-0.745\right)
$$

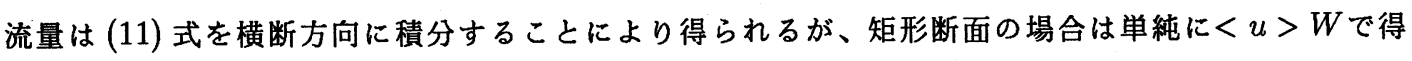
られる。

<方法 2>与えられた断面形状および潤辺粗度における流量は (1) 式により得られる断面内の流速 $u$ を $(z, n)$ 平面内で積分することにより得られる。

図一7(a)および (b) はWilliams ${ }^{3}$ ) の実験における水深、勾配を用いてそれぞれ上記の方法 1 およ び 2 で計算された流量を単位幅流量の形で実測の流量と比較したすのである。(a)では側壁の影響が 考慮されていないので、計算結果のうち特に $W / D$ のさいるのについて実測値を大きく上回る傾向 が見られるが、(b)においてはこれが改善され実测值とよく一致した結果が得られている。 

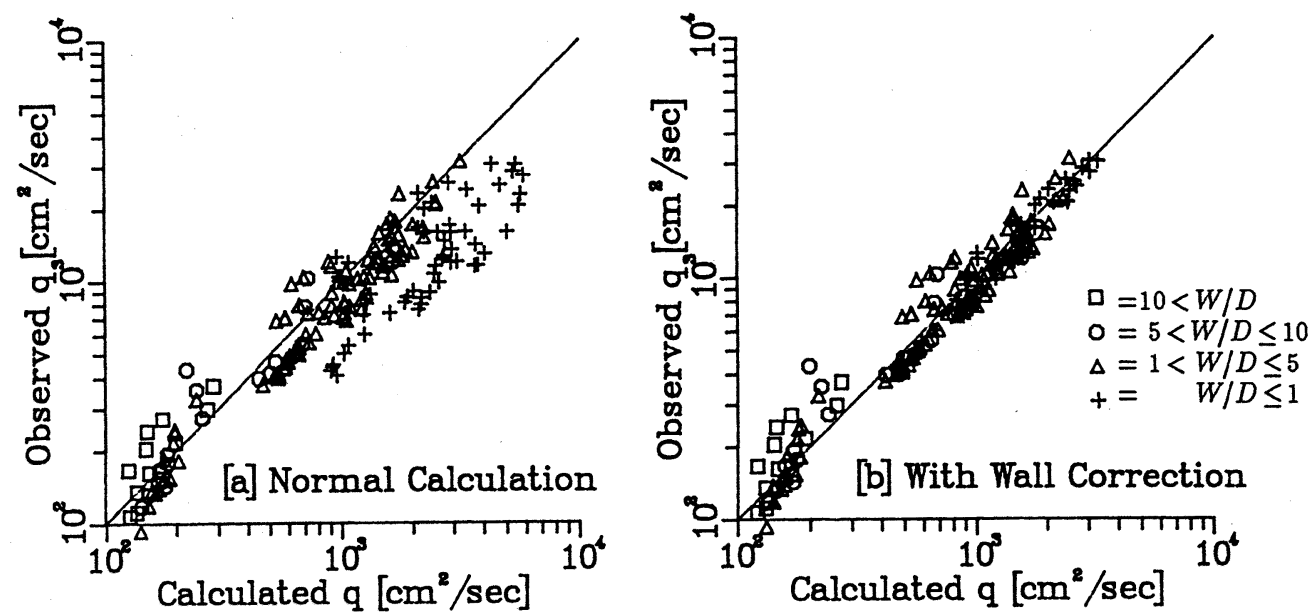

図-7 流量の計算結果と実測值の比較

\section{4. 結論}

開水路において断面内の主流の等流速線に直交する法線に沿って計算された渦動粘性係数を用いて運 動方程式を解くことにより、任意の断面形状を有する水路に於ける河床、河岸のせん断力分布の算定 方法を考案した。これにより、従来困難であった垂直側壁や急な河岸勾配を有する水路側岸近傍のせ ん断力分布の合理的な算定が可能となった。この方法を用いて既往の実験資料を再整理した結果、従 来の水深・勾配法に比へ、水路幅・水深比の極端に小さな条件においてす精度の良い流砂量や流量の 予測が可能となった。一般に、流砂量の実験データと流砂量式の比較を行う場合、実測值のばらつき や流砂量式との不一致は実験に伴う誤差や流砂量式の精度上の問題と見なされがちである。しかしな がら、本研究では河床せん断力を適切に算定することによりデータのばらつきや流砂量式との不一致 が改善されることが示され、精度の良い河床せん断力の算定法の重要性が改めて認識された。

\section{参考文献}

1) 江頭進治、黒木幹男、澤井健二、山坂昌成 : 開水路における河床せん断力の推定法、第 32 回水理講演会論 文集、pp.503-521、1988.

2) Rattray, M. Jr. and Mitsuda E.:Theoretical analysis of conditions on a salt wedge, Estuaric and Coastal Marine Science, 2, pp.373-394, 1974.

3) Williams, G. P.:Flume width and water depth effects in sediment-transport experiments., Prof. Paper 562-H, U.S.G.S., 1970.

4) Wiberg, P. L. and Smith, J. D.:Model for calculating bed load transport of sediment, J. Hydr. Div. ASCE, 115(1), pp.101-123, 1989.

5) Nikuradse, J.:Lows of flow in rough pipes, NACA Tech. Memo, 1933.

6) Nelson, J. M. and Smith, J. D.:Evaluation and stability of erodible channel beds, River Meandering, AGU, Water Resources Monograph, 12, pp.321-377, 1989.

7) Fernandez Luque, R., and van Beek, R. :Erosion and transport of bed-load sediment, J. Hydr. Res., 14(2), pp.127-144,1976.

8) Yalin, M. S. :An expression for bed load transportation, J. Hydr. Div. ASCE, 89(HY3), pp.221-250, 1963.

9) Einstein, H. A.:The bed load function for sediment transportation in open channel flows, Tech. Bulletin No. 1026, U.S.D.A., Soil Conserv. Service, pp.1-71, 1950. 